\title{
ANÁLISE DA SEGURANÇA DO TRABALHO NA ATIVIDADE DE CABELEIREIROS
}

Congresso Nacional Online de Empreendedorismo, 3ạ edição, de 06/12/2021 a 08/12/2021 ISBN dos Anais: 978-65-81152-30-7

SOUZA; Roberta Marinho de ${ }^{1}$

\section{RESUMO}

Introdução: Os primeiros registros referentes à Segurança do Trabalho ocorreram no século IV a. C. na Grécia. Ao longo dos anos, a segurança dos colaboradores, no ambiente de trabalho passou a ser regulamentada por leis e normas. No Brasil, as primeiras leis estabelecidas em relação à segurança dos trabalhadores passaram a vigorar a partir da Consolidação das Leis do Trabalho (CLT), em seguida vieram as Normas Regulamentadoras e outras leis. Essas normas e leis abrangem todas as atividades, independente do setor ou porte. Logo, o presente estudo abordara a atividade de microempreendedores individuais que trabalham na atividade como cabeleireiros, já que dados fornecidos pelo SEBRAE (2021) indicam que este setor obteve um número expressivo em seu crescimento, mesmo em um período pandêmico. Objetivos: Dessa forma, o trabalho tem por objetivo realizar análise das atividades dos cabeleireiros/as que são empreendedores, buscando identificar os principais riscos encontrados nessa atividade. Além disso, demonstrar aspectos relacionados ao aumento da produtividade gerada ao realizar a identificação e solução dos riscos encontrados. Método: A metodologia utilizada foi à pesquisa bibliográfica, através da análise de artigos referentes à temática. Resultados: Como resultado das pesquisas foi obtido que a atividade que causa maior desconforto nesses profissionais é a escovação de cabelos. Através da análise de artigos foi possível identificar a presença dos riscos ergonômicos gerados no processo de escovação, como também os físicos (causados pelos ruídos originados do secador de cabelo) e os químicos (utilização de produtos químicos, dentre eles o formol). Na busca por realizar a mitigação desses riscos é indicado o uso de equipamentos de proteção individual (máscara, luva, avental e óculos). Além disso, em análise foi percebido que os profissionais possuem e conhecem os EPIs, no entanto, muitas das vezes acabam não os utilizando ao realizarem as atividades. Logo, as soluções que são apresentadas seriam as paradas e o uso dos EPIs sempre que fosse necessário. No caso do uso de produtos químicos, como o formol, é preferível que não seja feita sua utilização, mas se for utilizado que seja em local ventilado e arejado. Em relação, ao risco de ruído foi indicado o uso de secadores que possuem o Selo Ruído. Conclusão: Em suma, com a identificação dos riscos e elaboração de formas cuja finalidade foi mitigar os riscos, foi possível melhorar as condições de trabalho e em consequência observado as melhorias na produtividade, já que a qualidade do ambiente do trabalho melhora a qualidade de vida do colaborador, que é o responsável pela execução da tarefa. 
PALAVRAS-CHAVE: Cabeleireiros, Empreendedorismo, Ergonomia, MEI, Segurança do Trabalho 